\title{
Effect of Calcination Temperature on Performance of Photocatalytic Reactor System for Seawater Pretreatment
}

\author{
Weerana Eh Kan, Jamil Roslan, Ruzinah Isha* \\ Faculty of Chemical \& Natural Resources Engineering, University Malaysia Pahang, Lebuhraya \\ Tun Razak, 26300 Pahang, Malaysia
}

Received: 22nd January 2016; Revised: 23 ${ }^{\text {rd }}$ February 2016; Accepted: 23rd February 2016

\section{Abstract}

Conservative desalination technology including distillation requires high energy and cost to operate. Hence, pretreatment process can be done prior to desalination to overcome energy demand and cost reduction. Objective of this research is to study the effect of calcination temperature of hybrid catalyst in photocatalytic reactor system in the seawater desalination, i.e. salt removal in the seawater. The catalyst was synthesized via wet impregnation method with $1: 1$ weight ratio of $\mathrm{TiO}_{2}$ and activated oil palm fiber ash (Ti:Ash). The catalyst was calcined at different temperature, i.e. $500{ }^{\circ} \mathrm{C}$ and $800{ }^{\circ} \mathrm{C}$. The study was carried out in a one liter Borosilicate photoreactor equipped with mercury light of 365 nanometers for two hours with $400 \mathrm{rpm}$ mixing and catalyst to seawater sample weight ratio of 1:400. The Chemical Oxygen Demand (COD), $\mathrm{pH}$, dissolved oxygen (DO), turbidity and conductivity of the seawater were analyzed prior and after the testing. The fresh and spent catalysts were characterized via X-Ray Diffractogram (XRD and Nitrogen physisorption analysis. The calcination temperature significantly influenced the adsorption behaviour and photocatalytic activity. However, Ti:Ash which calcined at $800{ }^{\circ} \mathrm{C}$ has less photocatalytic activity. It might be because the surface of fiber ash was sintered after calcined at high temperature. The Ti:Ash catalyst that calcined at $500{ }^{\circ} \mathrm{C}$ was found to be the most effective catalyst in the desalination of seawater by reducing the salt concentration of more than $9 \%$ compared to Ti:Ash calcined at $800{ }^{\circ} \mathrm{C}$. It can be concluded that catalyst calcination at $500{ }^{\circ} \mathrm{C}$ has better character, performance and economically feasible catalyst for seawater desalination. Copyright (C) 2016 BCREC GROUP. All rights reserved

Keywords: Pre-treatment; Oil palm waste; photocatalyst; Seawater; Titanium Dioxide

How to Cite: Kan, W.E., Roslan, J., Isha R. (2016). Effect of Calcination Temperature on Performance of Photocatalytic Reactor System for Seawater Pretreatment. Bulletin of Chemical Reaction Engineering \& Catalysis, 11 (2): 230-237 (doi:10.9767/bcrec.11.2.554.230-237)

Permalink/DOI: http://dx.doi.org/10.9767/bcrec.11.2.554.230-237

\section{Introduction}

The processing or desalination of natural seawater converted to drinking water by using various methods are increasing throughout the

* Corresponding Author.

E-mail: ruzinah@ump.edu.my

Telp: +609-5492891, Fax: +609-5492889 world [1]. Seawater becomes the main water source worldwide. In fact, Middle East and North Africa have relied on desalted seawater as their viable solutions in restraining the water shortage [2]. Seawater contains high total dissolved solid and it is called salinity. The existing technology such as membrane processes and distillation processes required high energy consumption to convert the seawater become 
the fresh water [3]. Indeed, the innovative method for seawater desalination is needed to improve the quality and source of drinking water. Because of the high energy of seawater desalination processes, alternative pre-treatment processes of seawater needed to be develop to save some energy consumption in seawater desalination for example removing some of salts from the seawater before desalinating processes take over to produce fresh water.

The updated technologies, such as: photocatalyst for the seawater purification, have been studied to receive the sign of inadequate water in the future. During the last decade, photocatalytic reaction, a technique of advanced oxidation processes (AOP) has been an alternative to the water and wastewater treatment [4]. Photocatalyst are semiconductors that have capabilities to cause or accelerate the chemical reactions upon light absorption notably sunlight [5] can be one of the alternative ways to be use in seawater pre-treatment. Indeed, commercially available photocatalytic water treatment plant using artificial UV-light as the energy source is available and can be considered applied in the photoreaction system [6]. Currently, many researches on water purification using the semiconductor photocatalyst by $\mathrm{TiO}_{2}$ catalyst are carried out. $\mathrm{TiO}_{2}$ catalyst becomes well-known in the research field and industrial field. $\mathrm{TiO}_{2}$ catalyst also becomes the important materials in many practical applications and is used as a desiccant, brightener or reactive radiator [6] and also can be applied in energy catalyst (in water splitting to produce hydrogen fuel), an environmental catalyst (in water and air purification) or an electron transport medium (in dye-sensitized solar cells) [7].

$\mathrm{TiO}_{2}$ catalysts are naturally occurring oxide of titanium. $\mathrm{TiO}_{2}$ is the one of catalyst that has competent photocatalytic activity, high stability and lowest cost [8]. $\mathrm{TiO}_{2}$ has capability and efficiency in removing the wide range of pollutants. The removal of pollutant in a solution by $\mathrm{TiO}_{2}$ significantly improves the efficiency of photocatalyst [9] and allows the complete degradation of organic pollutants into harmless species such $\mathrm{H}_{2} \mathrm{O}$ and $\mathrm{CO}_{2}$ [10]. However, the formations of $\mathrm{CO}_{2}$ are not instantaneously but sometimes long-living intermediates and have been investigated as a limited extent [11]. The efficiency decomposition of high salt concentrations containing in seawater by adapting the application of $\mathrm{TiO}_{2}$ photochemical reaction will be investigated in this studies. The advantages of $\mathrm{TiO}_{2}$ are inexpensive, non-toxic, it has excellent in high production of hydroxyl radicals and stable in physical and chemical properties [12, 13].

The application of $\mathrm{TiO}_{2}$ catalyst in photoreaction is not well explored yet. Modified the surface of $\mathrm{TiO}_{2}$ is one of the promising way to enhance the photocatalytic performance. Zeolite, carbon nanotube and active carbon are among porous substrate providing pore structures for dispersing $\mathrm{TiO}_{2}$ photocatalyst [14]. Oil palm fiber ash contains an active carbon and can be a promising adsorbent for the removal of the pollutants in the water. Moreover, oil palm fiber ash also has some minerals like Alumina, Calcium oxide and silica which can also act as an adsorbent in purifying water [15]. Malaysia produced over 11.9 million tons of oil and biomass was produced approximately 100 million tons by 6 million hectares of plantations in $\mathrm{Ma}$ laysia [16]. Combining $\mathrm{TiO}_{2}$ with various nanocarbon materials enhances photocatalytic activities by controlling the band gap to photosensitization, mineralization of $\mathrm{e}-\mathrm{h}+$ recombination, etc. [17].

In this study, the effect of calcination temperature on the hybrid catalyst Ti:Ash and its photocatalytic activity on seawater desalination were investigated. Biomass ash derived from oil palm fiber ash was used as a support for $\mathrm{TiO}_{2}$ photocatalyst for seawater desalination. The hybrid $\mathrm{TiO}_{2}$ and biomass ash catalyst was synthesized via wet impregnation technique with $500{ }^{\circ} \mathrm{C}$ and $800{ }^{\circ} \mathrm{C}$ calcination temperature.

\section{Materials and Methods}

\subsection{Materials and catalyst preparation}

Oil palm ash was obtained from Felda Lepar Hilir 3 Palm Oil Mill, Gambang, Kuantan, Pahang. $\mathrm{TiO}_{2}$ was purchased from Sigma Aldrich with $99 \%$ purity. The seawater was obtained from Teluk Cempedak, Kuantan Pahang (Latitude: 3.815, Longitude: 103.363). The seawater was kept at $4{ }^{\circ} \mathrm{C}$.

The catalyst was prepared via wet impregnation. A percentage weight ratio of $\mathrm{TiO}_{2}$ and oil palm ash (Ti:Ash) 50:50 was mixed with deionized water and stirred at $80{ }^{\circ} \mathrm{C}$ for four hours. It was then dried for overnight at $100^{\circ} \mathrm{C}$ in the oven. The catalyst was calcined for either $500{ }^{\circ} \mathrm{C}$ or $800{ }^{\circ} \mathrm{C}$ in the furnace for four hours. The catalyst was crushed and sieved to the size of $<100 \mu \mathrm{m}$ to have homogenized catalyst size.

\subsection{Catalyst characterization}

X-ray diffraction (XRD) patterns of the samples were collected on an X-ray powder diffrac- 
tometer. The samples of fresh and spent catalyst were scanned in the range from 10 to 80 of $2 \theta$. The BET surface area $\left(\mathrm{m}^{2} / \mathrm{g}\right)$, pore volume $\left(\mathrm{cm}^{3} / \mathrm{g}\right)$ and pore size $(\mathrm{nm})$ of each catalyst was obtained via nitrogen adsorption using Micromeritics ASAP2020. The catalyst was degassed up to $200^{\circ} \mathrm{C}$ for 6 hours prior to analyze.

\subsection{Photocatalytic reactor set up and catalyst testing}

All the experiments were carried out in a photocatalytic reactor as shown in Figure 1. The seawater sample to photocatalyst (Ti:Ash with a weight ratio of 50:50) was tested in a one liter borosilicate glass cylinder photocatalytic reactor equipped with UV light of $365 \mathrm{~nm}$ wavelength. This system was operated in a black box to prevent the UV light from exposure to the surrounding. The mixture of seawater and catalyst with a weight ratio of catalyst to seawater sample of 1:400 was tested in the reactor for two hours. The magnetic stirrer was used with a speed rotation of $400 \mathrm{rpm}$ to make sure that the solution was well mixed. Three regulator fans were installed to control the temperature of the black box in order to prolong the life span of the UV bulb.

After the investigation, the catalyst was filtered out from seawater. The quality of water was analyzed before and after the investigation. The $\mathrm{pH}, \mathrm{COD}$, conductivity, DO and turbidity of the water were determined. The measurement of seawater's acidity and alkalinity was determined by using $\mathrm{pH}$ meter (Hach Sension+ $150 \mathrm{~mm}$ ). Meanwhile, the conductivity was analyzed via Hach Sension+ $150 \mathrm{~mm}$ model. The amount of organic compound in the seawater was measured by using Hach (DRB 200) model. The COD Digestion Reagent Vial High Range (435 COD HR) was used to determine the COD. DO concentration for seawater was measured by using Dissolved Oxygen Meter (YSI 5100) model. Turbidity for seawater was measured by using Turbidity Meter Hach 2100 model. The collected gas was analyzed through gas chromatography (GC-TCD) model Agilent 19095p. The column oven held isothermally at $50{ }^{\circ} \mathrm{C}$, while the injector oven and detector were kept at $150^{\circ} \mathrm{C}$.

\section{Results and Discussion}

\subsection{Catalyst characteristic}

The catalyst was synthesized via wet impregnation method. The fresh and spent catalysts were characterized their surface structure and crystal structure by using $\mathrm{N}_{2}$ adsorption and XRD respectively.

The surface structure analysis result of Ti:Ash of 50:50 via $\mathrm{N}_{2}$ adsorption is tabulated in Table 1. Both catalysts are mesoporous in which those pores falls in the range of $2-50 \mathrm{~nm}$. The surface area of Ti:Ash catalyst that calcined at $500{ }^{\circ} \mathrm{C}$ was decreased from $9.15 \mathrm{~m}^{2} / \mathrm{g}$ to $6.67 \mathrm{~m}^{2} / \mathrm{g}$ as shown in Table 1 . The same trend is also obtained for its pore size. The pore size

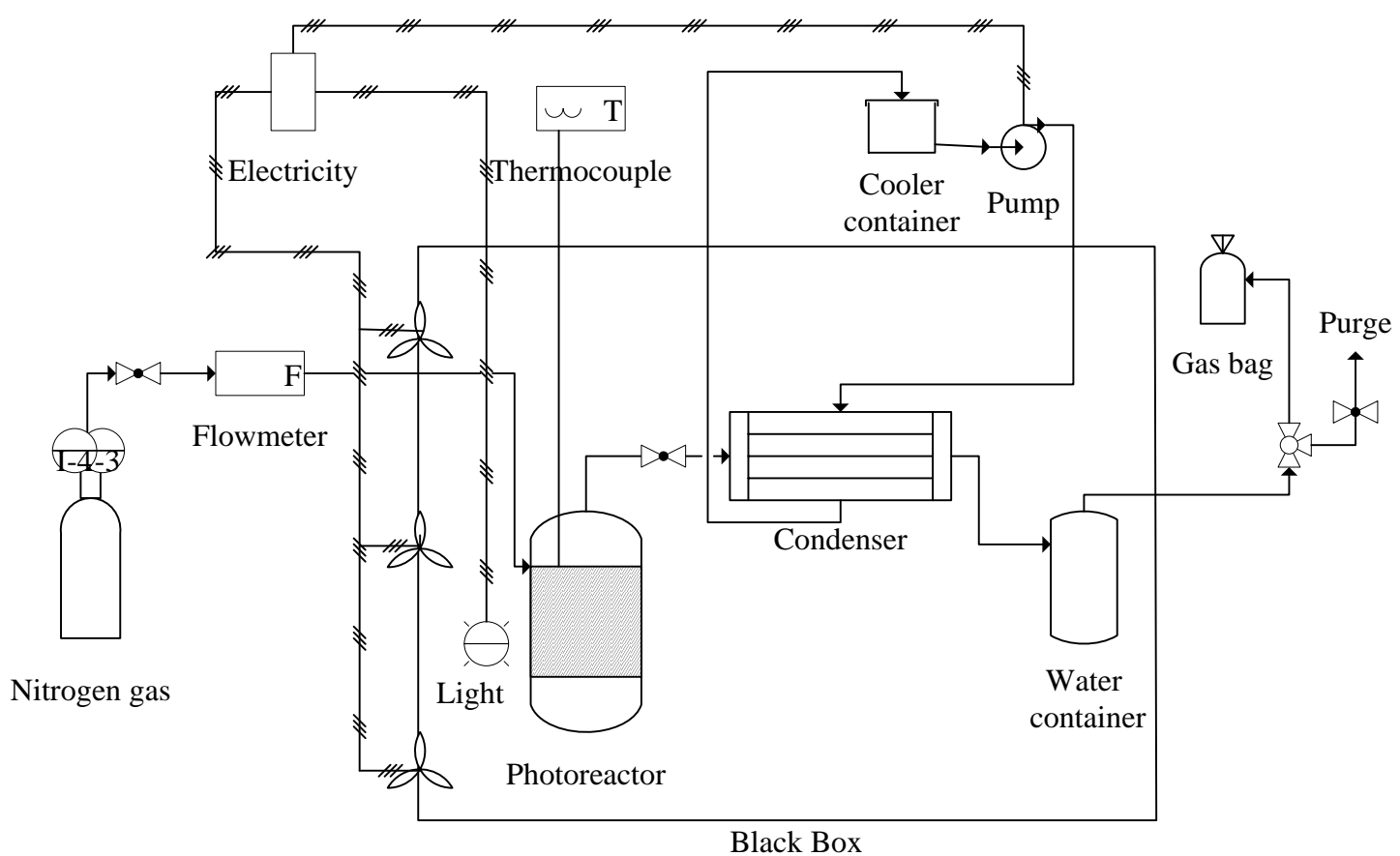

Figure 1. Schematic diagram of batch photocatalytic reactor set up 
reduced significantly from $18.63 \mathrm{~nm}$ to 15.54 $\mathrm{nm}$. In addition, pore volume also decreased from $3.49 \times 10^{-2} \mathrm{~cm}^{3} / \mathrm{g}$ to $2.29 \times 10^{-2} \mathrm{~cm}^{3} / \mathrm{g}$. This might be caused by the deposited crystal on the spent catalyst that leads to decrease the catalyst pore volume and pore size.

Meanwhile, Ti:Ash that calcined at $800{ }^{\circ} \mathrm{C}$ decreased from $5.98 \mathrm{~m}^{2} / \mathrm{g}$ to $5.47 \mathrm{~m}^{2} / \mathrm{g}$. Conversely, the pore volume and pore size of Ti:Ash that calcined at $800{ }^{\circ} \mathrm{C}$ increased after the testify from $1.34 \times 10^{-2} \mathrm{~cm}^{3} / \mathrm{g}$ to $1.59 \times 10^{-2} \mathrm{~cm}^{3} / \mathrm{g}$ and $13.59 \mathrm{~nm}$ and $15.01 \mathrm{~nm}$ respectively. In comparison with Ti:Ash that calcined at $500{ }^{\circ} \mathrm{C}$, the Ti:Ash that calcined at $800{ }^{\circ} \mathrm{C}$ has smaller surface area, pore volume and pore size. This may be due to the surface of Ti:Ash that calcined at $800{ }^{\circ} \mathrm{C}$ was breakage and damaged during calcination. High calcination temperature play the main role to destroy the surface of Ti:Ash catalyst. It is claimed that the crystalline structure of $\mathrm{TiO}_{2}$ will be changed after calcination at high temperature and the specific surface area, particle size and other properties of $\mathrm{TiO}_{2}$ can also be altered after calcinations at difference temperature [6].
Figure 2 illustrates that the XRD patterns for both Ti:Ash that calcined at $500{ }^{\circ} \mathrm{C}$ and 800 ${ }^{\circ} \mathrm{C}$ before and after the testing. It clearly can be seen that the presence of the salt at certain peak is detected on the both spent catalysts. The spent catalyst for Ti:Ash that calcined at $500{ }^{\circ} \mathrm{C}$ indicates that the present of $\mathrm{NaCl}$ phase peaks at $31.75^{\circ}, 45.47^{\circ}$ and $56.53^{\circ}$. The crystalline phase of spent Ti:Ash that calcined at $800{ }^{\circ} \mathrm{C}$ also shares the same peak profile. Yalçin and Mutlu [18] also reported that the salt peak did present around $30^{\circ}$ to $60^{\circ}$. It can be seen that the salt peaks of Ti:Ash calcined at temperature of $500{ }^{\circ} \mathrm{C}$ after were bigger compared to Ti:Ash calcined at temperature $800{ }^{\circ} \mathrm{C}$. It indicates that the catalyst at $500{ }^{\circ} \mathrm{C}$ has better efficiency in absorbance activity compared to Ti:Ash that calcined at $800{ }^{\circ} \mathrm{C}$. The Ti:Ash catalyst that calcined at $800{ }^{\circ} \mathrm{C}$ adsorbed lesser amount of salt as it might be because of the changes of crystalline structure due to calcination temperature affect.

Other than that, it also can be observed from fresh catalyst that calcined at $800{ }^{\circ} \mathrm{C}$ has smaller peak intensity in XRD patterns than

Table 1. BET of Ti:Ash catalyst that calcined at different temperatures

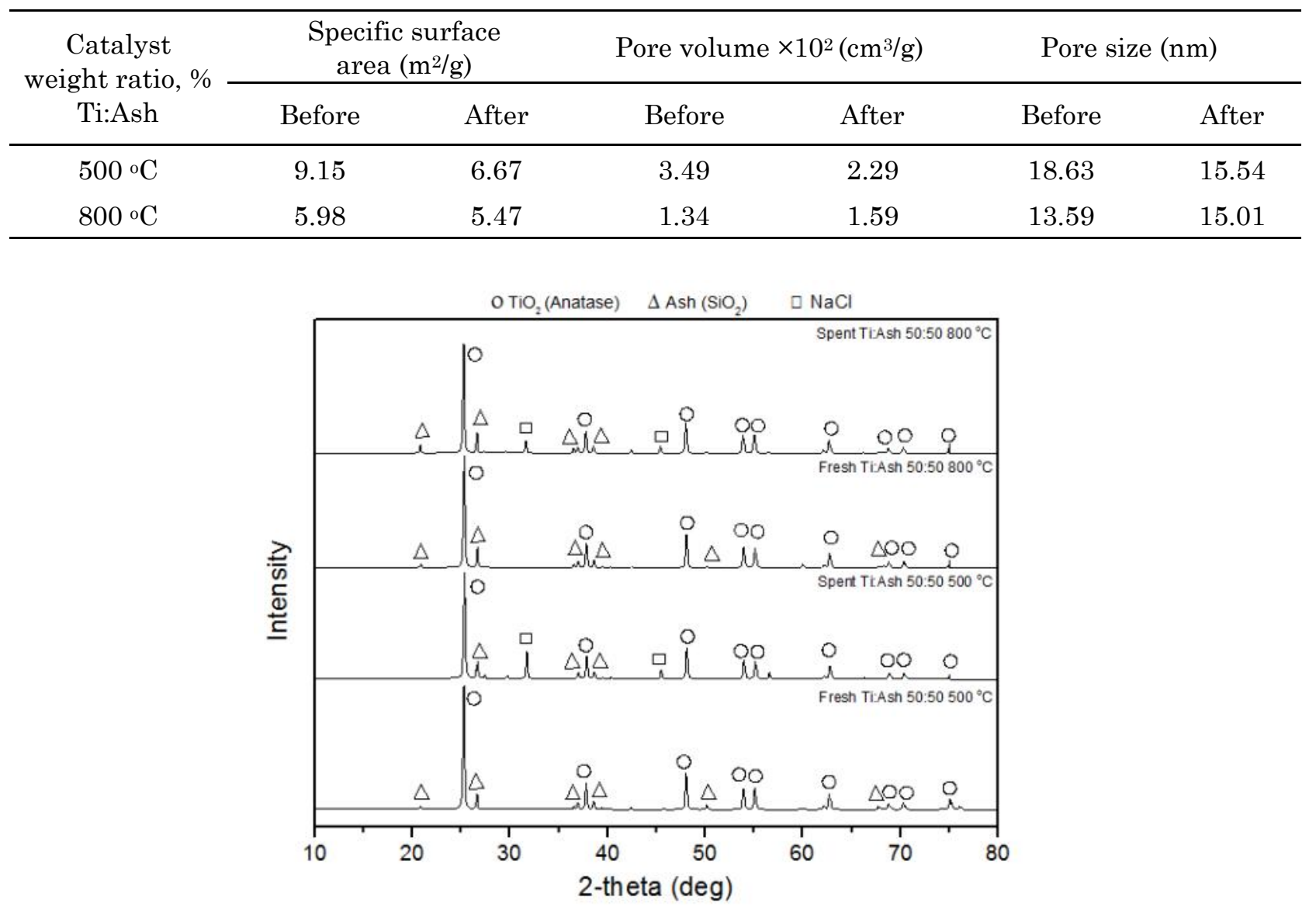

Figure 2. The XRD pattern of Ti:Ash before and after testify for different calcination temperature 
catalyst that calcined at $500{ }^{\circ} \mathrm{C}$. This might be caused by the effect of high calcination temperature $\left(800{ }^{\circ} \mathrm{C}\right)$ which ruined the raw structure of fiber ash. The major component of fiber ash is silica. Hirano et. al. [19] reported that the surface area decrease after high temperature $\left(800^{\circ} \mathrm{C}\right)$ affect that strike the surface area change due to sintering of the silica matrix but not to change the titania form.

According to Sun et al. [20], the improvement of the crystallinity of $\mathrm{TiO}_{2}$ was related to the high calcination temperature. $\mathrm{TiO}_{2}$ have a predominant crystal structure of anatase type crystal phase (Figure 2). No obvious diffraction peaks of $\mathrm{TiO}_{2}$ was detected for the both calcined temperatures, as the fresh Ti:Ash remained to be dominated by anatase phase. No extra peaks detected, such as rutile or rutileanatase mixed phase of $\mathrm{TiO}_{2}$. This might be the $\mathrm{TiO}_{2}$ particles have better thermal stability on the surface of fiber ash. Besides, the presence of fiber ash might suppress the diffusion between anatase crystallite and interface on the surface of the anatase crystallite. The effect created by promoter such as silica $\left(\mathrm{SiO}_{2}\right)$ led to the crystallite growth retarded and causes the suppression of the phase transformation [19].

Jamieson and Olinger [21] had reported that the transformation of anatase phase to rutile phase is not instantaneous; it is dependent on time because it is reconstructive and depends on the synthesis parameters, which in turn effect on the catalyst phase. The parameters that had been reported were impurities from raw materials and container, morphology of the catalyst, sample preparation technique, heating rate, surface area, particle size, volume of sample, supporting materials (dopants) and etc. [22]. It is claimed that the anatase was easily transformed to rutile phase when heated approximately or above at temperature of $600{ }^{\circ} \mathrm{C}$ to $800{ }^{\circ} \mathrm{C}[23,24]$. But, a study stated that the impurities present in anatase influence the transformation in the range of $600{ }^{\circ} \mathrm{C}$ to 1100
${ }^{\circ} \mathrm{C}$ temperatures [25]. The investigation was done by Hirano et al. [19] also indicates that the anatase phase maintain after heating at $1000{ }^{\circ} \mathrm{C}$ and no trace of rutile up to $1300{ }^{\circ} \mathrm{C}$. Anatase phase is necessary for photocatalytic reaction because the anatase phase is more photoactive than rutile $[6,26]$.

\subsection{Effect of calcination to water desalination process}

The investigation on the parameter of seawater which was $\mathrm{pH}$, conductivity, Turbidity, COD and DO was carried out. Table 2 tabulates the result of the seawater desalination via photocatalytic reaction.

It can be observed that better water quality was obtained after using the Ti:Ash catalyst in treating the seawater. Table 2 indicates that the percentage reduction of turbidity after the testing was achieved more than $90 \%$ for both catalysts. Moreover, the cloudiness of water also reduces significantly after filtration to separate the catalyst from seawater. In addition, it also can be observed that the COD of Ti:Ash that calcined at $500{ }^{\circ} \mathrm{C}$ reduced from $770 \mathrm{mg} / \mathrm{L}$ to $580 \mathrm{mg} / \mathrm{L}$ which signifies of up to $24 \%$ reduction compared to Ti:Ash that calcined at $800{ }^{\circ} \mathrm{C}$. The Ti:Ash catalyst that calcined at $800{ }^{\circ} \mathrm{C}$ only managed to decline from $770 \mathrm{mg} / \mathrm{L}$ to $655 \mathrm{mg} / \mathrm{L}$ which was only up to 14 $\%$ reduction. It clearly proves that the Ti:Ash that calcined at temperature $500{ }^{\circ} \mathrm{C}$ shows better performance in purifying the seawater compared to Ti:Ash that calcined at temperature $800^{\circ} \mathrm{C}$.

The conductivity of seawater via Ti:Ash that calcined at $500{ }^{\circ} \mathrm{C}$ managed to reduce up from $48.7 \mathrm{mS} / \mathrm{cm}$ to $44.3 \mathrm{mS} / \mathrm{cm}$ which made up about $9 \%$ reduction. Meanwhile, Ti:Ash calcined at $800{ }^{\circ} \mathrm{C}$ reduced from $48.7 \mathrm{mS} / \mathrm{cm}$ to $47.3 \mathrm{mS} / \mathrm{cm}$ ( $2 \%$ reduction) is also can be seen in Table 2. The photoreduction activity that occurred on the catalyst surface active site and

Table 2. The data analysis of seawater desalination

\begin{tabular}{lccc}
\hline \multicolumn{1}{c}{ Seawater Sample } & $\begin{array}{c}\text { Seawater sample } \\
\text { (Initial) }\end{array}$ & Ti:Ash, $500{ }^{\circ} \mathrm{C}$ & Ti:Ash, $800{ }^{\circ} \mathrm{C}$ \\
Analytical test & 48.7 & 44.3 & 47.3 \\
Conductivity (mS/cm) & 770 & 580 & 655 \\
COD (mg/L) & 2.78 & 0.11 & 0.08 \\
Turbidity (NTU) & 8.17 & 7.57 & 7.65 \\
pH & 5.44 & 5.59 & 5.50 \\
DO (mg/L) & & & \\
\hline
\end{tabular}


adsorption of salt in seawater is the reason why the conductivity of seawater declined after the testing. The Ti:Ash catalyst that calcined at $500{ }^{\circ} \mathrm{C}$ are able to adsorb more salt in seawater compared to Ti:Ash that calcined at $800{ }^{\circ} \mathrm{C}$. The results demonstrate that the adsorption capacity of samples was well agreed with XRD analysis (Figure 2).

The adsorption of salt on Ti:Ash surface is a prerequisite for the photocatalytic reduction. It also can be observed that the Ti:Ash that calcined at $800^{\circ} \mathrm{C}$ has lower surface area and has smaller pore size than Ti:Ash that calcined at $500{ }^{\circ} \mathrm{C}$. The Ti:Ash that calcined at $800{ }^{\circ} \mathrm{C}$ does not change much after the test. This effect might be reason why Ti:Ash that calcined at $800{ }^{\circ} \mathrm{C}$ has lower activity than Ti:Ash that calcined at $500{ }^{\circ} \mathrm{C}$. It is because calcination temperature at $500{ }^{\circ} \mathrm{C}$ led to higher surface area of Ti:Ash (as tabulated in Table 1) and be the responsible to improve the adsorption capacity and photocatalytic activity. In addition, high calcination temperature leads to gasify carbon in the oil palm fiber ash. Carbon is fully gasified at $600{ }^{\circ} \mathrm{C}$ [27]. Activated carbon is considered as an adsorbent for effluent treatment and is commonly utilized for the eliminating of various pollutants [28]. As higher calcination temperature was applied, less activated carbon remained in the catalyst. This might also be the reason of less adsorption capacity of Ti:Ash catalyst that calcined at $800{ }^{\circ} \mathrm{C}$. Rubio et al., [29] also reported that the adsorption of inorganic materials on the $\mathrm{TiO}_{2}$ can form a thick layer making it less penetrable by light resulting in the $\mathrm{TiO}_{2}$ less effective in terms of promoting the formation of oxygen radicals and bacterial inactivation. In addition, this factor that might happen during photocatalysis resulted to block the active sites of catalyst by adsorption of ions on the surface of $\mathrm{TiO}_{2}$ [1].

The value of DO increased in the seawater after the testing as shown in Table 2. The higher oxygen present in water might be because of the water splitting reaction during photocatalysis process. Fresh water holds more oxygen compared to saltwater. As the amount of salt in water decreases, the amount of dissolved oxygen increases. The DO value of seawater treated by Ti:Ash catalyst that calcined at $800{ }^{\circ} \mathrm{C}$ is lower than seawater treated by Ti:Ash that calcined at $500^{\circ} \mathrm{C}$. The $\mathrm{DO}$ value in the seawater that treated with the Ti:Ash catalyst that calcined at $500{ }^{\circ} \mathrm{C}$ increased to 5.59 $\mathrm{mg} / \mathrm{L}$. Meanwhile, the DO value of seawater treated by Ti:Ash catalyst that calcined at 800 ${ }^{\circ} \mathrm{C}$ increased to $5.50 \mathrm{mg} / \mathrm{L}$. Higher calcination temperature might result to decomposition of anatase phase in $\mathrm{TiO}_{2}[6,26]$. It is also a prove that anatase pahe of $\mathrm{TiO}_{2}$ (Figure 2) significantly influence the efficiency of the catalyst.

The effect of Ti:Ash catalyst on seawater by utilizing the photocatalytic reactor system seems satisfied because it could reduce the $\mathrm{pH}$ value in the seawater after treatment. The result in Table 2 signifies that the Ti:Ash that calcined at $500{ }^{\circ} \mathrm{C}$ and $800{ }^{\circ} \mathrm{C}$ reduced the $\mathrm{pH}$ of seawater to 7.57 and 7.65 respectively. Ti:Ash that calcined at $500{ }^{\circ} \mathrm{C}$ managed to reduce the $\mathrm{pH}$ value up to $7 \%$ reduction, otherwise Ti:Ash that calcined at $800{ }^{\circ} \mathrm{C}$ managed to reduce the $\mathrm{pH}$ value up to $6 \%$ reduction. $\mathrm{pH}$ plays an important role in photocatalytic degradation of organics content in the seawater. The slight reduction in $\mathrm{pH}$ value might be because due to the multitude intermediate formation by products that might cause different chemical functional groups and will affect the value of $\mathrm{pH}$ indifferently [30]. Surface charge property of $\mathrm{TiO}_{2}$, organic molecule charge, the adsorption of organic molecule on to $\mathrm{TiO}_{2}$ surface a hydroxyl radical concentration are the effects of $\mathrm{pH}$ solution [31].

The gas collected was analyzed via gas chromatography with thermal conductivity detector (GC-TCD) tested on both Ti:Ash catalyst that calcined at temperature $500{ }^{\circ} \mathrm{C}$ and $800{ }^{\circ} \mathrm{C}$. This investigation is to verify that the reaction also occur in the photocatalyst system by using Ti:Ash catalyst. The presence of small amount of $\mathrm{CO}_{2}$ for both catalyst conditions was detected by GC-TCD. Seawater alone was tested in the photocatalytic system to investigate the gas contained in the seawater itself. The molar percentage of $\mathrm{CO}_{2}$ contain in the seawater was $0.0168 \%$. The reaction occur by using the Ti:Ash catalyst that calcined at $500{ }^{\circ} \mathrm{C}$ produced $0.022 \%$ amount of $\mathrm{CO}_{2}$, while Ti:Ash catalyst that calcined at $800{ }^{\circ} \mathrm{C}$ generated $0.028 \%$ amount of $\mathrm{CO}_{2}$. However, the $\mathrm{CO}_{2}$ gas produced from the reaction is very minute. The $\mathrm{CO}_{2}$ was produced due to the reaction of organic matter with $\mathrm{OH}$. Hydroxyl production generated from water splitting during photocatalytic reaction. Yoneyama and Torimoto [32] also claimed that adsorbed substances in the adsorbent support are oxidized that produced $\mathrm{CO}_{2}$, It is a proof that the catalyst has dual function which is as an adsorbent and catalyst in light wavelength of $365 \mathrm{~nm}$ exposure.

\section{Conclusions}

In this paper, the investigation on the effect of catalyst calcination temperature towards $\mathrm{TiO}_{2}$ supported by oil palm fiber ash was stud- 
ied. The catalyst was prepared via wet impregnation technique and tested in the photocatalyst reactor scheme. The phase of anatase in $\mathrm{TiO}_{2}$ appeared at both Ti:Ash catalyst at $500{ }^{\circ} \mathrm{C}$ and $800{ }^{\circ} \mathrm{C}$ and does not strongly influenced by calcination temperature. The XRD shows that the both catalyst are able to adsorb salt $(\mathrm{NaCl})$. It is found that the adsorption and photocatalyst ability of hybrid catalyst Ti:Ash significantly depended on the calcination temperature. The result indicates that the Ti:Ash calcined at temperature $500{ }^{\circ} \mathrm{C}$ performed better adsorption capacity and reactivity compared to $800{ }^{\circ} \mathrm{C}$ catalyst calcination. It is shown that the oil palm fiber ash could be the supporter in purifying the seawater. Better $\mathrm{pH}$, conductivity, COD, DO and turbidity values and amount of gas generated specially $\mathrm{CO}_{2}$ were achieved and indicated that the catalyst has dual functions; adsorbent and catalyst.

\section{Acknowledgments}

The authors acknowledge the support of Ministry of Malaysia of Higher Education and Universiti Malaysia Pahang for Master scholarship for Weerana Eh Kan and Jamil Roslan and research support of RDU140388.

\section{References}

[1] Al-Rasheed, R., Cardin, D.J. (2003). Photocatalytic degradation of humic acid in saline waters. Part 1. Artificial seawater: influence of $\mathrm{TiO}_{2}$, temperature, $\mathrm{pH}$, and air-flow. Chemosphere 51: 925-933.

[2] Ghaffour, N., Reddy, V.K., Abu-Arabi, M. (2011). Technology Development and Application of Solar Energy in Desalination: MEDRC contribution. Renewable and Sustainable Energy Reviews 15: 4410-4415.

[3] Shakhashiri (January 2011). Chemical of the Week; Water for General Chemistry. Citing Internet sources URL www.scifun.org

[4] Mozia, S., Toyoda, M., Inagaki M., Tryba, B., Morawski, A.W. (2007). Application of Carbon-coated $\mathrm{TiO}_{2}$ for Decomposition of Methylene Blue in a Photocatalytic Membrane Reactor. Hazardous Materials 140: 369-375.

[5] Serpone, N., Emiline, A.V. (2002). Suggested Terms and Definitions in Photocatalysis and Radiolysis. International Journal of Photoenergy (4): 91-131.

[6] Ibhadon, A.O., Fitzpatrick, P. (2013). Heterogeneous Photocatalysis: Recent Advances and Applications. Catalysts 3: 189-218; doi:10.3390/catal3010189.
[7] Lazar, M.A., Varghese, S., Nair, S.S. (2012). Photocatalytic Water Treatment by Titanium Dioxide: Recent update. Catalyst 2: 572-601; doi:10.3390/catal2040572.

[8] Hashimoto, K., Irie, H., Fujishima, A. (2005). $\mathrm{TiO}_{2}$ Photocatalysis: A Historical Overview and Future Prospects. Japanese Journal of Applied Physics 44(12): 8269-8285.

[9] Shon, H.K., Vigneswaran, S., Kim, J., Huu, H.N. (2007). Application of Hybrid Photocatalysis Systems Coupled with Flocculation and Adsorption to Biologically Treated Sewage Effluent for Organic Removal. Korean Journal of Chemical Engineering, 24(4): 618-623.

[10] Shon, H.K., Phuntsho, S., Vigneswaran S. (2007). Effect of Photocatalysis on the Membrane Hybrid System for Wastewater Treatment, Technical Report, Faculty of Engineering, University of Technology, Sydney, NSW 2007, Australia.

[11] Carp, O., Huisman, C.L., Reller, A. (2004). Photoinduced Reactivity of Titanium Dioxide. Progress in Solid State Chemistry 32: 33-177.

[12] Klankaw, P., Chawengkijwanich, C., Grisdanurak, N., Chiarakorn, S. (2012). The Hybrid Photocatalysis of $\mathrm{TiO}_{2}-\mathrm{SiO}_{2}$ Thin Film Prepared from Rice Husk Silica. Superlattices and Microstructures 51: 343-352.

[13] Chai, Y-S., Lee, J-C., Kim, B-V. (2000). Photocatalytic Disinfection of E. coli in a Suspended $\mathrm{TiO}_{2} / \mathrm{UV}$ Reactor. Korean J. Chem. Eng., 17(6): 633-637.

[14] Guo, B., Shen, H., Shu, K., Zeng, Y., Ning, W. (2009). The Study of the Relationship between Pore Structure and Photocatalysis of Mesoporous $\mathrm{TiO}_{2}$. Chemical Science, 121(3): 317-321.

[15] Awal, A.S.M., Hussin M.W. (1997). The Effectiveness of Palm Oil Fuel Ash in Preventing Expansion due to Alkali-Silica Reaction. Cement and Concrete Composites, 19(4): 367372.

[16] Abdul, K.H.P.S., Poh, B.T., Issam, A.M., Jawaid, M., Ridzuan, R. (2010). Recycled Polypropylene-oil Palm Biomass: The Effect on Mechanical and Physical Properties. Reinforced Plastics and Composites 29(8): 11171130 .

[17] Lee, S-Y., Park, S-Y. (2013). $\mathrm{TiO}_{2}$ Photocatalyst for Water Treatment Applications. Industrial and Engineering Chemistry 19: 17611769.

[18] Yalcin, S., Mutlu, I.H. (2012). Structural Characterization of Some Table Salt Samples by XRD, ICP, FTIR and XRF Techniques. In Proceedings of the International Congress on Advances in Applied Physics and Materials Science, Antalya 2011. Vol. 121. 
[19] Hirano, M., Ota, K., Iwata, H. (2004). Direct Formation of Anatase $\left(\mathrm{TiO}_{2}\right) /$ Silica $\left(\mathrm{SiO}_{2}\right)$ Composite Nanoparticles with High Phase Stability of $1300{ }^{\circ} \mathrm{C}$ from Acidic Solution by Hydrolysis under Hydrothermal Condition. Chemical Material, 16(19): ): 3725-3732

[20] Sun, Q., Hu, X., Zheng, S., Sun, Z., Liu, S., Li, H. (2015). Influence of Calcination Temperature on the Structural, Adsorption and Photocatlaytic Properties of $\mathrm{TiO}_{2}$ Nanoparticles Supported on Natural Zeolite. Powder Technology 274: 88-97.

[21] Jamieson, J.C., Olinger, B. (1968). HighPressure Polymorphism of Titanium Dioxide. Science, 161: 893-895.

[22] Dorian, A.H., Sorrell, C.C. (2011). Review of the Anatase to Rutile Phase Transformation. Material Science 46: 855-874.

[23] Porter, J.F., Li, Y.G., Chan, C.K. (1999). The Effect of Calcination on the Microstructural Characteristics and Photoreactivity of Degussa P25 $\mathrm{TiO}_{2}$. Material Science. 34(7): 15231531.

[24] Li, W., Ni, C., Lin, H., Huang, C.P., Ismat, S.S. (2004). Size Dependence of Thermal Stability of $\mathrm{TiO}_{2}$ Nanoparticles. Applied Physics 96: 6663-6668 (doi: 10.1063/1.1807520)

[25] Emerson, F.H., Clair W.W. (1972). Kinetics, Mechanism of the Anatase/Rutilse Transformation, as Catalysed by Ferric Oxide and Reducing Conditions. American Mineralogist 57: 10-23.
[26] Ahmed, S., Rasul, M.G., Brown, R., Hashib, M.A. (2011). Influence of Parameters on the Heterogeneous Photocatalytic Degradation of Pesticides and Phenolic Contaminants in Wastewater: A Short Review. Environmental Management, 92(3): 311-330.

[27] Isha, R. \& Williams, P.T. (2011) Pyrolysisgasification of agriculture biomass wastes for hydrogen production. Journal of the Energy Institute, 84: 80-87

[28] Bansal, R.C., Goyal, M. (2005). Activated Carbon Adsorption. CRC Press, New York.

[29] Rubio, D., Casanueva, J.F., Nebot, E. (2013). Improving UV Seawater Disinfection with Immobilized $\mathrm{TiO}_{2}$ : Study of the Viability of Photocatalysis (UV254/ $\left.\mathrm{TiO}_{2}\right)$ as Seawater Disinfection Technology. Photochemistry and Photobiology A: Chemistry 271: 16-23.

[30] Stylidi, M., Kondarides, D.I., Verykios, X.E. (2003). Pathways of Solar Light-induced Photocatalytic Degradation of Azo Dyes in Aqueous $\mathrm{TiO}_{2}$ Suspensions. Appl. Catal. B: Environ. 40: 271-286.

[31] Aliabadi, M., Abyar, A. (2013). Photo Catalytic Degradation of Acrylonitrile in Aqueous Solutions Using Nano Titanium Dioxide. Biodiversity and Environment Sciences, 3(12): 36-42.

[32] Yoneyama, H., Torimoto, T. (2000). Titanium Dioxide/Adsorbent Hybrid Photocatalysts for Photodestruction of Organic Substances of Dilute Concentrations. Catalysis Today 58: 133-140.

Selected and Revised Papers from The International Conference on Fluids and Chemical Engineering (FluidsChE 2015) (http://fluidsche.ump.edu.my/index.php/en/) (Malaysia, 25-27 November 2015) after Peer-reviewed by Scientific Committee of FluidsChE 2015 and Reviewers of BCREC 